\title{
Effect of Self Esteem and Self Efficacy on Work Satisfaction and Its Implication on Teacher Performance (Study at SDN 1 Legokpego, Desa Drawati, Kecamatan Paseh, Bandung District)
}

\author{
$1^{\text {st }}$ Wandy Zulkarnaen \\ STIE Muhammadiyah \\ Bandung/Muhammadiyah University \\ Bandung \\ wandy.zulkarnaen@stiemb.ac.id
}

\author{
$2^{\text {nd }}$ Yayan Sofyan \\ STIE Muhammadiyah \\ Bandung/Muhammadiyah University \\ Bandung
}

\author{
$3^{\text {rd }}$ Iis Dewi Fitriani \\ STIE Muhammadiyah \\ Bandung/Muhammadiyah University \\ Bandung
}

\begin{abstract}
The purpose of this study was to determine the effect of self esteem and self efficacy on Work Satisfaction and Its Implications on Teacher Performance at SDN 1 Legokpego Drawati Village, Paseh District, Bandung Regency. This research was carried out by taking samples of Teacher of SDN 1 Legokpego Drawati Village, Paseh Subdistrict, Bandung Regency, which amounted to 39 people. Analysis of the results of this study uses path analysis. As for the results of the study as follows: The self efficacy variable directly determines changes in the Work Satisfaction variable by $31.5 \%$. through self efficacy of $13.5 \%$. the effect of total self esteem on Work satisfaction by $45.1 \%$. self efficacy has a direct effect on Work satisfaction by $16.9 \%$. through Self esteem of $13.6 \%$. the effect of total self efficacy on Work Satisfaction is $30.5 \%$. The magnitude of the contribution of the independent variable to the dependent variable, according to the results of the calculation of the total direct and indirect effects obtained 0.755 thus it can be said the contribution of the three variables is $75.5 \%$ while the remaining $24.5 \%$ is the contribution of other variables not examined. The effect of Work satisfaction on teacher performance by $80.3 \%$, while the remaining $19.7 \%$ Teacher Performance is caused by other variables outside the independent variables that are not involved in this study, such as motivational variables, locus of control, leadership and etc.
\end{abstract}

Keyword-self esteem, self efficacy, Work satisfaction, teacher performance

\section{INTRODUCTION}

As the most important factor is often associated with success or failure in achieving an organization's goals even referred to as the most decisive thing in the organization. Organizational goals based on Human Resources can be effectively achieved if the human factor is empowered through the implementation of the Human Resources function as a whole.

In facing the era of globalization required superior human resources by all organizational entities including public organizations in achieving organizational goals.
The Government of Indonesia is demanded to realize good governance (good governance), good public services, efficient, effective and quality, so in realizing the governance system, it is necessary to support Human Resources, especially teachers who are professional, responsible, fair, honest and competent in their field. In other words, the teacher in carrying out the task must be based on professionalism and competence according to the qualifications of his field of science.

Creating potential and quality human resources is not simple, the problem is that teachers who are professional and have high competence are still "dreams" rather than reality.

Teacher's teaching load is set at least 24 hours face-to-face and at most 40 hours face-to-face in 1 week in one or more units of education. Teacher structuring is the process of rearranging so that the ratio, academic qualifications, distribution, and composition of teachers according to their individual needs education unit, this shows the development of Human Resources in formal education, depending on the teacher as the spearhead of education providers. Teachers must have adequate quality, because teachers are the core component and role takers in the education process at school

Teacher performance is one of the causes of declining school quality. Therefore. To improve teacher performance in teaching, all teachers must meet the demands stipulated in the law, among others, the teaching staff is tasked with carrying out administration, management, development, supervision, and technical services to uphold the educational process in the education unit

Decentralization of education through the implementation of School-Based Management as an effort to improve the quality of education in schools. SDN 1 Legokpego Desa Drawati, Paseh Subdistrict, Bandung Regency is one of the schools that continues to strive to 
improve the quality of education by implementing School Based Management, where schools have autonomy in school managerial management by involving the community and local government.

To overcome these problems, it is necessary to improve the performance of all schools, including the teachers as one of the work units, where they are in direct contact with students.

Teacher performance is assessed in terms of both quality and quantity, which is the work standard determined by the school. Called performance is good if it is in accordance with standards set for organizational goals. Organizations are said to be good when trying to improve the ability of human resources, because it is a key factor to improve performance.

Based on the results of a preliminary survey through a questionnaire distributed to students to assess the performance of each teacher, the results can be seen as follows:

TABLE I. PERFORMANCE EMPIRICAL DATA

\begin{tabular}{|c|c|c|c|c|}
\hline \multirow{2}{*}{ Question } & \multicolumn{2}{|c|}{ Yes } & \multicolumn{2}{|c|}{ No } \\
\hline & amount & $\%$ & amount & $\%$ \\
\hline $\begin{array}{l}\text { SDN } 1 \text { Legokpego teachers plan learning materials according to } \\
\text { the curriculum }\end{array}$ & 12 & 40.00 & 18 & 60.00 \\
\hline $\begin{array}{l}\text { Teacher SDN } 1 \text { Legokpego able to develop and use technical } \\
\text { knowledge in teaching }\end{array}$ & 14 & 46.67 & 16 & 53.33 \\
\hline Teacher SDN 1 Legokpego very cooperative in teaching & 10 & 33.33 & 20 & 66.67 \\
\hline Teacher SDN 1 Legokpego come to teach in a timely manner & 13 & 43.33 & 17 & 56.67 \\
\hline
\end{tabular}

Source: Data processed2019

Based on table 1, it can be seen that 12 teachers assessed by their superiors plan learning materials according to the curriculum, while the remaining 18 people are still assessed as not planning. A total of 14 teachers were rated by the principal to be able to develop and use technical knowledge in teaching, while the remaining 16 people were still considered unable. A total of 10 teachers are considered to be very cooperative in teaching, while the remaining 20 are still considered uncooperative. And as many as 13 teachers came to teach on time, while the remaining 17 were not on time. Based on this, it can be concluded that teacher performance is not optimal.

One internal factor that is associated with the achievement of performance is the attitude and behavior aspects of work and the environment. Hopwood (2011: 45), said that this is related to aspects of Work satisfaction. A teacher who feels Work satisfaction will do a good Work, whereas teachers who do not get Work satisfaction will decrease their performance.

The following are presented data from the results of a preliminary survey regarding Work satisfaction:

TABLE II. EMPIRICAL DATA ON WORK SATISFACTION

\begin{tabular}{|c|l|c|c|c|c|}
\hline \multirow{2}{*}{ No } & \multicolumn{1}{|c|}{ Statement } & \multicolumn{2}{c|}{ Yes } & \multicolumn{2}{c|}{ No } \\
\cline { 3 - 6 } & \multicolumn{1}{|c|}{ amount } & \%ount & \multicolumn{2}{c|}{ \% } \\
\hline 1 & I feel satisfied teaching at SDN 1 Legokpego & 16 & $53.33 \%$ & 14 & $46.67 \%$ \\
\hline 2 & If I teach well, then I will be promoted & 10 & $33.33 \%$ & 20 & $66.67 \%$ \\
\hline 3 & $\begin{array}{l}\text { The principal at SDN 1 Legokpego provided } \\
\text { support for me }\end{array}$ & 10 & $33.33 \%$ & 20 & $66.67 \%$ \\
\hline 4 & $\begin{array}{l}\text { I really enjoy teaching at SDN 1 Legokpego because } \\
\text { teacher colleagues can be invited to work together }\end{array}$ & 8 & $36.67 \%$ & 22 & \multirow{2}{*}{$63.33 \%$} \\
\hline
\end{tabular}

Source: Data processed

Based on table II can be seen from 30 teachers, 6 teachers who were satisfied teaching, the remaining 14 people still felt less satisfied. As many as 10 people agree that if they carry out their teaching assignments well, they will be promoted, while the remaining 20 disagree. As many as 10 teachers rated the school principal to support the teacher, while the remaining 20 people rated that there was no support from the school principal. as many as 8 teachers really enjoyed teaching with friends from work units, while the remaining 22 people did not fully enjoy.

Based on these data it appears that 15 teachers were dissatisfied in various matters such as promotions, coworkers and supervision by the school principal. This happens because there are still differences between the existing reality and teacher expectations.

Many things can affect the performance and Work satisfaction of a teacher, both internal and external. There are two factors that influence a teacher's performance, namely individual factors and environmental factors. Individual factors include, physical and mental are used to complete the task, personal nature, and role perception. Environmental factors include physical condition, equipment, time, material, education, supervision, organizational design, training and so on (Byars \& Rue, 2009).

Self efficacy is one of the internal factors that influence satisfaction, where self efficacy is an individual's belief to motivate himself in carrying out specific tasks consisting of self-confidence considerations. While the consequences of self efficacy are behaviors and attitudes consisting of Work satisfaction (Novan, 2011).

Self efficacy determines how much effort is spent and how individuals survive in the face of obstacles and painful experiences. The stronger the perception of self efficacy, the more active and persevering the efforts. When faced with difficulties, the individual has great doubts about his ability to reduce his efforts or give up altogether. Whereas those who have strong feelings of efficacy use greater effort to overcome challenges. In other words, human efforts to achieve something and to 
create a positive self-existence require an optimistic sense of personal efficacy. This is because social reality is usually full of difficulties so people must have a strong sense of personal excellence to maintain a firm effort in the face of difficulties and obstacles, then this is where the role of self-confidence is taken into account.

Weak self efficacy is an obstacle to progress and hinders the ability to overcome other obstacles effectively. Low self efficacy can hinder effort even though individuals have skills and cause easy despair. The teacher knows that his action will produce something, but is not sure of his ability to do the action.

Self-efficacy occurs in SDN 1 Legokpego Drawati Village teachers, Paseh District, Bandung Regency, where from the preliminary survey results there are still teachers who know that their actions will produce certain consequences but they are not sure of their abilities in carrying out these actions.

Another factor that influences Work satisfaction is self esteem. self esteem is a tendency for someone to see himself as having the ability to overcome challenges in life and have the right to be happy. individuals who have high self-confidence will have good self-confidence, have the ability to solve problems better than feeling worried about the problem, have the ability to take risks with decisions made and maintain and care for themselves.

Researchers conducted a preliminary study of 30 teachers relating to self esteem pricess, as shown in Table III

TABLE III. EMPIRICAL SELF ESTEEM DATA

\begin{tabular}{|l|c|c|c|c|}
\hline \multicolumn{1}{|c|}{ Preliminary Questions } & \multicolumn{3}{c|}{ The answer } \\
\hline & Agree & Neutral & Disagree & amount \\
\hline I feel a valuable person & 6 & 6 & 18 & 30 \\
\hline I feel the work is valued by all colleagues & 9 & 6 & 15 & 30 \\
\hline I feel I have some good quality work & 6 & 6 & 18 & 30 \\
\hline
\end{tabular}

Based on table 3 it can be seen that the respondents who answered disagree as many as 51 people, who answered agree as many as 21 the rest answered neutral
18 this indicates the teacher's self esteem is not optimal Next, the researcher conducts preliminary research related to self efficacy, as shown in Table IV

TABLE IV. SELF-EFFICACY INTRODUCTION QUESTIONNAIRE

\begin{tabular}{|l|c|c|c|c|}
\hline \multicolumn{1}{|c|}{ Preliminary Questions } & Agree & Neutral & Disagree & amount \\
\hline I am sure that I can do a heavy task & 11 & 5 & 14 & 30 \\
\hline I was given an assignment by the leader, I was sure I could do it & 10 & 5 & 15 & 30 \\
\hline I am always confident that I can complete the task well & 12 & 6 & 12 & 30 \\
\hline
\end{tabular}

Source: Processed Data (2019)

From the table above it can be seen that the majority of respondents (41 disagree) about the preliminary research results distributed by the author and those who answered agree as much as (33) the rest answered neutral (16) this indicates the teacher's self-efficacy variable is not optimal.

From the results of the preliminary research it can be concluded that almost half of the respondents still have low confidence in their ability or potential.

\section{LITERATURE REVIEW AND HYPOTHESIS}

\section{A. Self esteem}

According to (Kreitner and Kinicki, 2007: 165). self esteem is a value of self value based on overall self evaluation. Feelings - feelings of self-esteem are in fact shaped by our circumstances and how other people treat us. self esteem is measured by positive and negative statements. The positive statement in the self esteem survey is "I feel that I am someone who is very meaningful, like everyone else, while negative statements are" I feel that I don't have much to be proud of "

People who agree with positive statements and disagree with negative statements have high self esteem where they see themselves as valuable, capable and acceptable. People with low self esteem do not feel good about themselves.

According to Slavin (2008: 91) " self esteem is the values that exist in themselves, abilities and behavior". Based on the word self-esteem, it can be interpreted as a person's appreciation for himself because what is in a person is a strength that must be valued and developed B. Self efficacy

According to Baron and Byrne (2011: 42) self-efficacy as a person's evaluation of his ability or competence to carry out a task, achieve goals, and overcome obstacles. While Bandura and Woods explained that self-efficacy refers to the price of an individual's ability to drive motivation, cognitive abilities, and actions needed to meet the demands of a situation.

Based on the explanation of self efficacy, it can be stated conceptually self efficacy is the price of a person for the ability he has to carry out the task as well as possible, with indicators: (1) feeling able to complete the task; (2) feeling of being able to make decisions; and (3) readiness to accept work risks

C. Work Satisfaction 
According to Robbins (2007: 184) the term Work satisfaction is the relationship between an individual and his work and environment. The term Work satisfaction is an individual's general attitude towards his Work. Someone with a high level of Work satisfaction shows a positive attitude towards the Work, someone who is dissatisfied with the Work shows a negative attitude towards the Work

Wexley \& Yukl (2009: 129) states that Work satisfaction is a way an employee feels satisfaction about his work.

According to Luthans (2006: 230), Work satisfaction as a positive emotional state resulting from appreciation for one's work or one's work experience. Furthermore, Luthans also emphasized that Work satisfaction is the result of employees' perceptions of how well a person's Work is in giving everything that is seen as important through his work. The term Work satisfaction refers to the attitude (emotional reaction) of an individual to his work

D. The performance

According to Mathis \& Jackson (2009: 78) Performance is basically what employees do or don't do. Employee performance is what influences how much they contribute to the organization. These include:

- Quantity of output

- Output quality

- The period of output

- $\quad$ Presence at work

- Cooperative attitude

So the conclusions of the authors state that employee performance is a function and interaction between abilities, motivation, and popular opportunities, where the level of success in carrying out tasks and the ability to achieve the stated goals is the work quality and quantity achieved by an employee in carrying out his duties according to the responsibilities given to him

E. Hypothesis

The hypothesis set based on the above thoughts is as follows:

- There is an effect of self-esteem on the Work satisfaction of teachers at SDN 1 Legokpego Drawati Village, Paseh District, Bandung Regency partially

- There is an effect of self-efficacy on the Work satisfaction of SDN 1 Legokpego teacher, Drawati Village, Paseh District, Bandung Regency partially

- There is an influence of Work satisfaction on teacher performance at SDN 1 Legokpego Drawati Village, Paseh District, Bandung Regency partially

- There is an effect of self-esteem and self-efficacy on Work satisfaction of elementary school teachers 1 Legokpego Drawati Village Paseh District Bandung Regency simultaneously

\section{RESEARCH METHODS}

The research method used in this research is descriptive method. Descriptive method is a research method that describes a problem that is then analyzed to produce conclusions. Descriptive research studies problems in society, as well as procedures that apply in society and certain situations, including about relationships, activities, attitudes, views, and processes that are ongoing and the effects of an phenomenon (Nazir, 2003)

\section{RESEARCH RESULTS AND DISCUSSION}

- Based on the results of the study, Self-esteem has a positive and significant effect on Work Satisfaction in SDN 1 Legokpego Teachers in Drawati Village, Paseh District, Bandung Regency.

- Based on the results of the study, Self efficacy has a positive and significant effect on Work Satisfaction.

- Self esteem and Self efficacy have a significant effect on Work Satisfaction.

- Work Satisfaction has a positive influence on Teacher Performance

\section{CONCLUSION}

- Self esteem has an average weight of 3.65 with good criteria.

- Self efficacy, obtained results with an average value of 3.52 with Good criteria

- Work Satisfaction has an average value of 3.60 with Good criteria.

- Based on the results of research on performance, obtained respondents' answers with an average value of 3.68 with good criteria but there is a weak aspect that is I always give direction to students and I have a program to increase student learning hours

- Self esteem has a positive and significant influence on Work Satisfaction in SDN 1 Legokpego Teachers in Drawati Village, Paseh District, Bandung Regency.

- Self efficacy has a positive and significant effect on Work satisfaction.

- Self esteem and Self efficacy have a significant effect on Work Satisfaction.

- Work Satisfaction has a positive influence on Teacher Performance.

\section{REFERENCES}

[1] Aikaterini Gkolia.2014. Investigate the relationship between job satisfaction and self-efficacy experienced by general employees and teachers, as it rises through the literature review

[2] Bandura, Albert \& Locke, Edwin. A. 200 5. Negative Self-Efficacy and Goal Effects Revisited. Journal of Applied Psychology. Vol. 88, No. 1, 87-99

[3] Baron, RA., \& Byrne R. 2004. Social Psychology Volume 1 (Subtitles by Ratna Djuwita, Melania Meitty Parman, Dyah Yasmina \& Lita Lunanta). Jakarta: Erlangga Publisher.

[4] Bernardin, H, John and Russel, E, A, 2003, Human Resources Management: An Experimental Approach , Singapore, Mc Graw-Hill International Editions

[5] Brockner, J. 2008. Self-esteem at work: Research, theory, and practice. Lexington, MA: Lexington Books 
[6] Brown, B, L., 2001. Self-Efficacy Beliefs and Career Develoment, http://www.ed.gov/databases/ERIC-Digets/ed .

[7] Byars, L Lylod and Lesli W Rue.2008. Human Resource Management, 7 edition. New York: Mc Graw - Hill.

[8] Cervone, D., and Peake, PK 2006. Anchoring, Efficacy, and Action: The Influence of Judgment Heuristics on Self-Efficacy Judgment and Behavior. Journal of Personality and Social Psychology, Vol.50, 492-501

[9] Dessler, Gary. 2006. Personnel Management. Third Edition. Jakarta: Erlangga.

[10] Engko, Cecilia. 2008. Effect of Job Satisfaction on Individual Performance with Self Esteem and Self Efficacy as Intervening Variables. Journal of Business and Accounting Vol. 10, No. 1, April 1-12.

[11] Erez, A. And TA Judge. 2001. Relationship of Core Self Evaluations to Goal Settings, Motivation, and Performance. Journal of Applied Psychology. Vol. 86 No. 6, pp. 1270-1279.

[12] Ertanto, Dwi Yayan \& Suharnomo. 2010. Effect of Salary on Employee Performance with Self Esteem as an Intervening Variable; Study on PDAM Grobogan Regency. Journals.

[13] Feldman, RS. 2003. Social Psychology. New Jersey: Prentice-Hall Inc.

[14] Gaouzali, Saydam. 2000. Human Resource Management (A Micro Approach). Jakarta: Djambat.

[15] Gomes, Faustino Cardoso. 2003. Human Resource Management. Andi Publisher. Yogyakarta.

[16] Hary. 2007. Building Confidence. WorldPress.com

[17] Hariyanto, Novan. 2001. Analysis of the Effect of Self-Efficacy Factors on Performance, Job Satisfaction, and Organizational Commitment of Remote Workers (Teleworkers): Study of Online Internet Media Companies in Indonesia. Thesis Diponegoro University Semarang.

[18] http: //www.bppsdmk , 2008

[19] Husnawati, Ari. 2006. Analysis of the Effect of Quality of Work Life on Employee Performance with Commitment and Job Satisfaction as Intervening Variables. Thesis Diponegoro University Semarang.

[20] Johan, Rita. 2002. Job Satisfaction of Employees (Teachers) in the Environment of Educational Institutions. Jakarta: Atma Jaya Catholic University.

[21] Judge, TA and JE Bono. 2001. Relationship of Core Self Evaluations Self Esteem Traits, Gemeralized Self Efficacy,
Locus of Control and Emotional Stability by Job Satisfaction and Job Performance; a Meta analysis. Journal of Applied Psychology. Vol 86 No. 1 page 80-92.

[22] Kreitner, R. And A. Kinicki. 200 7. Organizational Behavior. Second Edition. Jakarta: Salemba Empat.

[23] Lawler III, 1998, Job Satisfaction and Expression of Emotion in Organizations

[24] Lee, C. \& Bobko P.2004, Self Efficacy Beliefs: Comparations of Five Measures, Journal of Applied Psychology, Vol. 79. no. 6, page. $819-825$

[25] Luthans, Fred. 200 6. Organizational Behavior. New York: McGraw-Hill

[26] Mangkunegara, anwar prabu. 2007. HR Performance Evaluation. PT Refika Aditama. Bandung

[27] Mangkuprawira, S. 2009. Business, Management, and Human Resources. Bogor: IPB Press.

[28] Martin CS Wong.2012. The Impact of Leadership Program on Self-Esteem and Self-Efficacy in Schools: A Randomized Controlled Trial

[29] Mathis and Jackson. 2009. Human Resource Management , First Edition ,. Salemba Empat, Jakarta

[30] Mondy, RW \& noe, MR 2005. Human Resource Management ( $9^{\text {th }}$ Ed). New Jersey. Pearson Education, Inc., Upper Saddle River.

[31] Rivai, 2005 , The Effect of Salary Satisfaction, Job Satisfaction and Organizational Commitment Against Outgoing Intentions: Empirical Testing of the Turnover Lum Lum et al Model , Journal of Business and Accounting, April, 335 - 352

[32] Robbins, Stephen. P. 2007. Organizational Behavior. New Jersey: Prentice Hall.

[33] Schyns, B., and GV Collani. 2002. A New Occupational Self Efficacy Scale and its Relation to Personality Construction and Organizational Variables. European Journal of Work and Organizational Psychology. 11 (2). Pp. 219-241.

[34] Schunk, D. H. 2013. Self-Efficacy, Motivation, and Performance

[35] Sudjana. 2002. Statistics Method. Bandung: Tarsito.

[36] Sugiyono 2013. Statistics for Research. Bandung: Alfabeta.

[37] 2013. Business Research Methods. Bandung: Alfabeta.

[38] W. Gulo, 2002, Research Methodology, PT. Grasindo, Jakarta 